\title{
Major Elements Geochemistry of Sedimentary Rocks from Corumbataí Formation, Santa Gertrudes Ceramic Pole, São Paulo, Brazil
}

\author{
Maria Margarita Torres Moreno ${ }^{\mathbf{1}}$, Rogers Raphael da Rocha ${ }^{2}$, Letícia Hirata Godoy ${ }^{1}$ \\ ${ }^{1}$ Department of Petrology and Metalogeny, Institute of Geosciences and Exact Sciences, \\ Paulista State University, Rio Claro, Brazil \\ ${ }^{2}$ Cerâmica Rochaforte, Rio Claro, Brazil \\ Email: mmoreno@rc.unesp.br, godoylh@rc.unesp.br, rogers.rocha@rochaforte.com.br
}

Received November 20, 2013; revised December 20, 2013; accepted December 26, 2013

Copyright (c) 2014 Maria Margarita Torres Moreno et al. This is an open access article distributed under the Creative Commons Attribution License, which permits unrestricted use, distribution, and reproduction in any medium, provided the original work is properly cited. In accordance of the Creative Commons Attribution License all Copyrights (C 2014 are reserved for SCIRP and the owner of the intellectual property Maria Margarita Torres Moreno et al. All Copyright @ 2014 are guarded by law and by SCIRP as a guardian.

\begin{abstract}
We conducted a geochemical study of the major elements of 29 clay samples from 10 mining fronts, which are used for ceramic coatings at Santa Gertrudes Ceramic Pole, São Paulo, Brazil. This region is considered as the biggest ceramic pole in Latin America. The mines are located in Corumbataí Formation (Paraná Sedimentary Basin) and are mined in bench system. The samples were analyzed as a whole and along each profile to evaluate the variation of the concentration of major elements and weathering effects. The results show a differentiation into three groups: 1) carbonate clays; 2) lower portion samples; 3) upper portion samples, and properties that allow obtaining useful information about the use and selection of raw materials to the formulation of ceramic masses and for quality control of raw materials in order to achieve products of similar quality.
\end{abstract}

\section{KEYWORDS}

\section{Clay Minerals; Raw Material; Ceramic Coatings; Weathering}

\section{Introduction}

The raw material used in the ceramic pole of Santa Gertrudes (SP) naturally presents properties that define its greatness for ceramic coating, once it allows obtaining good quality products in relatively low temperatures, using dry milling process [1], which provides the reduction of energetic costs when compared to similar sedimentary rocks.

The material is from the top unit of Passa Dois Group sediments, known as Corumbataí Formation, inserted in the context of Paraná Sedimentary Basin, which was filled by sedimentary and basic igneous rocks whose age varies from Late Ordovician to Late Cretaceus [2,3]. This formation emerges in the region of the ceramic pole where the lithostratigraphy of the sedimentary basin is composed by seven units and its lower and upper contacts are with Irati and Pirambóia formations respectively.

Clays are dominantly illitic and exhibit differences in physical-chemical characteristics due to heterogeneity, which arise because of geological processes that lead to rock consolidation and weathering processes [4]. In order to use it in coating sector, normally two or more materials from the same formation are combined according to the desired type of product. The illites are associated with stratifications of mixed layers and pure clay minerals as chlorite, smectite and sometimes kaolinite, the last one in the upper levels [5]. Other minerals may follow the illites, such as quartz (always present), carbonate, hematite, feldspar (mostly sodic), analcime and others nondetected by $\mathrm{X}$ ray diffractometry in minor proportions.

Thus, the main objective of this paper is to evaluate the chemical composition of major elements of $10 \mathrm{~min}$ ing fronts in order to obtain useful information about the use and selection of raw materials to the formulation of ceramic masses and for quality control of raw materials in order to achieve products of similar quality. 


\section{Methods}

For this research we used chemical analyses of major elements from samples obtained by [1] in Acme Labs (Canada). Binary and ternary variation diagrams [6] were constructed from this data, in order to understand the distribution of elements in the study area and along each profile in different mining fronts. The samples were extracted with auger and each one represents one bench of the respective mining front. The mineralogy and granulometric distribution of milled samples were assessed by X Ray Diffractometry (Siemens D5000 equipment) and Laser Diffraction (Malvern Mastersizer 2000 equipment) respectively. Pressed ceramic bodies were prepared and their mechanical resistance determined through rupture tension measures with three points flexural test (Nannetti FM/96 fleximeter).

\section{Results and Discussion}

The chemical analyses of major elements from 10 clay mining fronts that belong to Corumbataí Formation are located in the municipalities that comprehend the "Santa Gertrudes Ceramic Pole” (SGCP), as shown in Figure 1.

Table 1 presents the results of chemical analyses for major elements in the oxide form (data reported by [1]), later showed in graphs that exhibit the variations in the sediments as a function of geological processes (sedimentation, diagenesis, hydrothermalism and weathering).

Except for Tute mine profile, which differentiate from the others by the high content of carbonates, the concentration of silica decrease in the lower-upper direction as a result of hydrolyses reactions of 2:1 clay minerals and feldspars, mainly sodic [7], that occurs simultaneously to the increase of both $\mathrm{Al}_{2} \mathrm{O}_{3}$ (less mobile) and loss on ignition (LOI) due to the highest hydration state of hydrolyses products [8]. In Figure 2 is showed the variation diagram of oxides with $\mathrm{Al}_{2} \mathrm{O}_{3}$ content increase. Aluminum was chosen because of its immobile character and due to the relatively broad range of variation [6].

The largest variation in the study area corresponds to sodium element since the concentration of albite is highly variable, even between same profile strata [9]. Iron

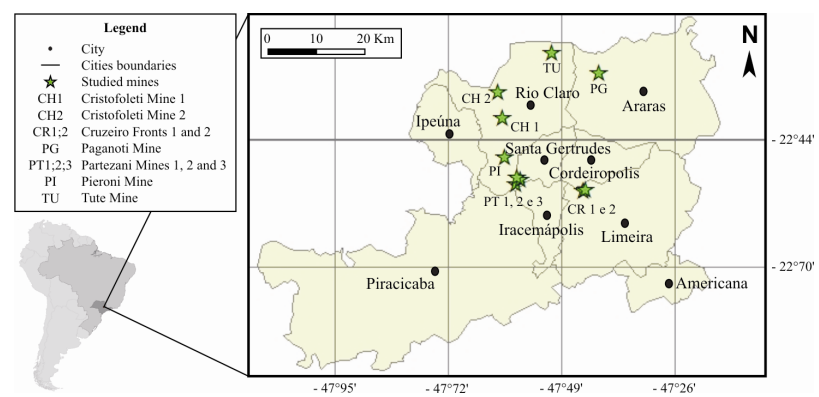

Figure 1. Location map of included mines in the geochemical analysis. increases along with aluminum, however, it presents some dispersion due to fluids circulation in several stages of sediments evolution, causing $\mathrm{Fe}^{2+}, \mathrm{Fe}^{3+}$ complex ions and colloidal particles movements $[8,10]$, which were heterogeneously deposited along the profile (Table 1). Calcium tends to decrease along the increase of $\mathrm{Al}_{2} \mathrm{O}_{3}$, except for carbonate samples with $\mathrm{CaO}$ content larger than 3\% (CH2_1, CR1_2, Tu1, Tu2, Tu3).

The oxides that display minor variation are $\mathrm{MgO}$ e $\mathrm{K}_{2} \mathrm{O}$. Potassium has its main origin associated with clay minerals of the illite family, due to the low content of potassium feldspar and other potassium bearing minerals in these materials. Loss on ignition reflects the presence of clay minerals and/or carbonates that release water and $\mathrm{CO}_{2}$ respectively.

Figure 3 shows that $\mathrm{MgO} / \mathrm{K}_{2} \mathrm{O}$ ratio, because of constant concentration, presents less variation when represented as a function of $\mathrm{SiO}_{2}$, which may be interpreted as a parti-

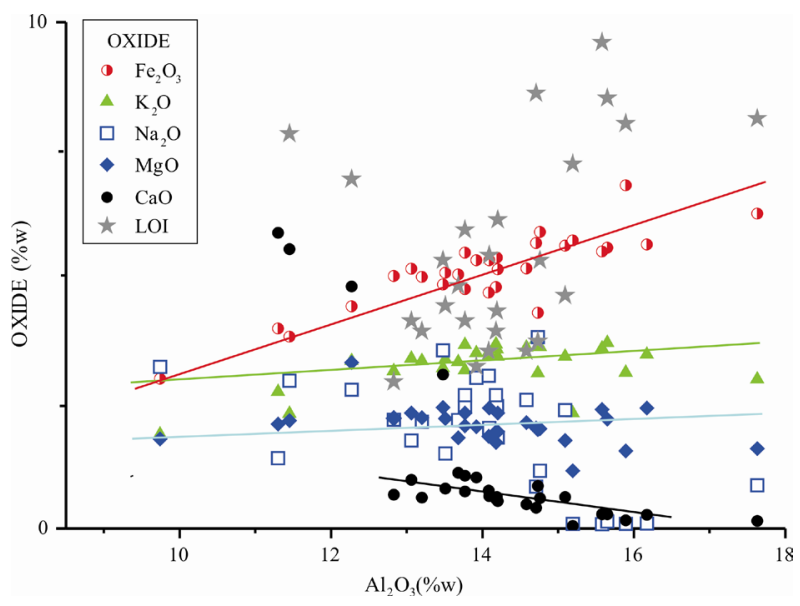

Figure 2. Oxide concentration variation according to aluminum oxide content.

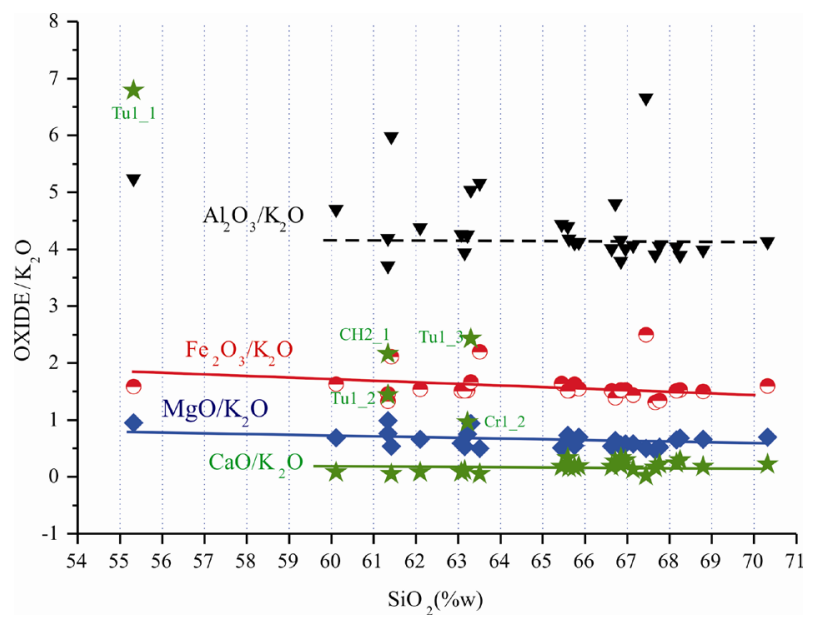

Figure 3. Oxide/ $\mathrm{K}_{2} \mathrm{O}$ ratio variation along with $\mathrm{SiO}_{2}$ increase, showing the particular regularity of the $\mathrm{MgO} / \mathrm{K}_{2} \mathrm{O}$ ratio for all samples. 
Table 1. Chemical composition of major elements expressed in the oxide form (data reported by [1]). The increasing numerical sequence of samples corresponds to the direction from lower to upper portions along each profile.

\begin{tabular}{|c|c|c|c|c|c|c|c|c|c|c|c|c|}
\hline Sample & $\mathrm{SiO}_{2}$ & $\mathrm{Al}_{2} \mathbf{O}_{3}$ & $\mathrm{Fe}_{2} \mathrm{O}_{3}$ & $\mathrm{TiO}_{2}$ & $\mathbf{K}_{2} \mathbf{O}$ & $\mathrm{Na}_{2} \mathrm{O}$ & MgO & MnO & $\mathrm{CaO}$ & $\mathbf{P}_{2} \mathbf{O}_{5}$ & ${ }^{*} \mathrm{LOI}$ & Sum \\
\hline CH1 1 & 65.75 & 14.76 & 5.86 & 0.62 & 3.59 & 1.14 & 1.97 & 0.04 & 0.60 & 0.18 & 5.3 & 99.82 \\
\hline CH1 2 & 63.07 & 15.65 & 5.55 & 0.63 & 3.67 & 0.14 & 2.16 & 0.05 & 0.28 & 0.07 & 8.5 & 99.78 \\
\hline CH1 3 & 62.10 & 15.58 & 5.47 & 0.65 & 3.56 & 0.08 & 2.35 & 0.05 & 0.28 & 0.07 & 9.6 & 99.80 \\
\hline CH2 1 & 61.34 & 11.30 & 3.95 & 0.45 & 2.70 & 1.39 & 2.06 & 0.11 & 5.84 & 0.15 & 10.4 & 99.70 \\
\hline CH2 2 & 60.11 & 16.17 & 5.61 & 0.66 & 3.44 & 0.10 & 2.38 & 0.06 & 0.27 & 0.10 & 10.9 & 99.81 \\
\hline CR1 1 & 66.96 & 13.92 & 5.30 & 0.60 & 3.47 & 2.98 & 2.01 & 0.06 & 1.01 & 0.24 & 3.2 & 99.76 \\
\hline CR1 2 & 63.22 & 13.48 & 4.82 & 0.57 & 3.17 & 3.52 & 2.39 & 0.10 & 3.04 & 0.14 & 5.3 & 99.77 \\
\hline CR2 1 & 66.85 & 13.77 & 5.45 & 0.58 & 3.63 & 2.40 & 2.03 & 0.04 & 0.73 & 0.26 & 4.1 & 99.85 \\
\hline CR2 2 & 66.63 & 14.19 & 5.35 & 0.61 & 3.54 & 2.42 & 1.91 & 0.05 & 0.62 & 0.17 & 4.3 & 99.80 \\
\hline CR2 3 & 65.45 & 15.09 & 5.59 & 0.65 & 3.40 & 2.34 & 1.74 & 0.09 & 0.62 & 0.16 & 4.6 & 99.75 \\
\hline PG 1 & 67.66 & 14.18 & 4.77 & 0.61 & 3.64 & 2.63 & 1.70 & 0.02 & 0.58 & 0.13 & 3.9 & 99.83 \\
\hline PG 2 & 67.76 & 14.08 & 4.66 & 0.59 & 3.48 & 3.02 & 1.82 & 0.04 & 0.75 & 0.14 & 3.5 & 99.85 \\
\hline PG 3 & 66.72 & 14.73 & 4.26 & 0.57 & 3.07 & 3.78 & 1.95 & 0.05 & 0.84 & 0.16 & 3.7 & 99.84 \\
\hline PG 4 & 61.42 & 17.63 & 6.22 & 0.74 & 2.95 & 0.85 & 1.58 & 0.07 & 0.15 & 0.06 & 8.1 & 99.79 \\
\hline PT1 1 & 68.25 & 13.06 & 5.13 & 0.56 & 3.36 & 1.74 & 2.28 & 0.03 & 0.96 & 0.34 & 4.1 & 99.82 \\
\hline PT1 2 & 65.62 & 14.20 & 5.12 & 0.60 & 3.40 & 1.80 & 2.28 & 0.03 & 0.54 & 0.12 & 6.1 & 99.82 \\
\hline PT1 3 & 65.85 & 14.09 & 5.30 & 0.60 & 3.42 & 1.99 & 2.38 & 0.03 & 0.64 & 0.14 & 5.4 & 99.85 \\
\hline PT1 4 & 65.59 & 13.77 & 4.73 & 0.57 & 3.13 & 2.63 & 2.28 & 0.06 & 1.04 & 0.14 & 5.9 & 99.85 \\
\hline PT2 1 & 68.79 & 13.20 & 4.97 & 0.58 & 3.31 & 2.11 & 2.19 & 0.03 & 0.61 & 0.17 & 3.9 & 99.87 \\
\hline PT2 2 & 67.14 & 14.58 & 5.14 & 0.62 & 3.58 & 2.54 & 2.09 & 0.03 & 0.48 & 0.11 & 3.5 & 99.82 \\
\hline PT2 3 & 66.85 & 13.68 & 5.02 & 0.57 & 3.29 & 2.14 & 1.79 & 0.04 & 1.10 & 0.57 & 4.8 & 99.86 \\
\hline PT3 1 & 67.44 & 15.19 & 5.69 & 0.65 & 2.28 & 0.09 & 1.14 & 0.03 & 0.05 & 0.10 & 7.2 & 99.87 \\
\hline PI 1 & 70.32 & 12.83 & 4.99 & 0.57 & 3.11 & 2.15 & 2.18 & 0.03 & 0.67 & 0.09 & 2.9 & 99.85 \\
\hline PI 2 & 68.16 & 13.51 & 5.05 & 0.58 & 3.34 & 1.48 & 2.17 & 0.04 & 0.79 & 0.34 & 4.4 & 99.87 \\
\hline PI 3 & 63.15 & 14.71 & 5.64 & 0.63 & 3.73 & 0.83 & 1.99 & 0.06 & 0.41 & 0.08 & 8.6 & 99.84 \\
\hline PI 4 & 63.51 & 15.89 & 6.78 & 0.67 & 3.08 & 0.09 & 1.53 & 0.06 & 0.16 & 0.07 & 8.0 & 99.85 \\
\hline TU 1 & 55.32 & 9.74 & 2.96 & 0.39 & 1.86 & 3.19 & 1.77 & 0.15 & 12.63 & 0.14 & 11.7 & 99.86 \\
\hline TU 2 & 61.34 & 12.27 & 4.39 & 0.51 & 3.31 & 2.74 & 3.28 & 0.08 & 4.78 & 0.21 & 6.9 & 99.82 \\
\hline TU 3 & 63.30 & 11.45 & 3.79 & 0.47 & 2.27 & 2.92 & 2.13 & 0.08 & 5.52 & 0.13 & 7.8 & 99.87 \\
\hline
\end{tabular}

"Loss on ignition.

cularity for these clays. Materials studied by [11] from Itararé Group, basal unity of Paraná Sedimentary Basin in the region, display $\mathrm{MgO} / \mathrm{K}_{2} \mathrm{O}$ values of approximately 13 for the less weathered strata and higher values for the others. In this case its use is destined for structural ceramic products and as an additive to correct the plasticity of ceramic masses for coating.
The $\mathrm{CaO}$ shows a pronounced variation regarding Tute (Tu) mine samples (higher carbonate content) and for CH2_1 and CR1_2 samples, in which the CaO comprehend more than $3 \%$.

The materials from Corumbataí Formation that are used in the ceramic coatings industries of SGCP comprehend the less weathered strata than those used for 
structural ceramic products. Figure 4 shows $\mathrm{MgO} / \mathrm{K}_{2} \mathrm{O}$ ratio values in each mining front, which present an irregular variation sometimes towards the top or the base within a specific range, caused mainly due to clayish strata permeability.

Weathering processes lead the evolution of illites to smectitic and/or kaolinitic minerals, therefore $\mathrm{MgO} / \mathrm{K}_{2} \mathrm{O}$ ratio tends to highest values along with potassium egress. Tute mine although show a different behavior, since it corresponds to the superior portion of the Corumbataí Formation stratigraphic column [12] and in the other mines this part of the column has already been eroded leaving intermediate and basal portions only.

The $\mathrm{Al}_{2} \mathrm{O}_{3},\left(\mathrm{MgO} / \mathrm{K}_{2} \mathrm{O}\right)$ and $\left(\mathrm{CaO}+\mathrm{Na}_{2} \mathrm{O}\right)$ parameters were plotted in a ternary diagram in order to assess the weathering effects over each profile (Figure 5). It is possible to notice the formation of an inverse evolution "trend" between aluminum and the elements that are considered to be farther mobile $\left(\mathrm{CaO}\right.$ e $\left.\mathrm{Na}_{2} \mathrm{O}\right)$. This sample alignment can be divided in three groups: 1) G1, 7 samples located in the upper portions of the mines; 2) G2, 17 samples of the lower portion except for Pt1_4 that has a high content in albite, detected by $\mathrm{x}$ ray diffractometry analysis; and 3) G3, 5 samples with $\mathrm{CaO}$ greater than 3\% due to higher carbonate content.

From the ceramic point of view, depending on the weathering state, raw materials present differential behavior, therefore having to be properly combined in order to formulate masses [1]. Usually raw materials that belong to $\mathbf{G} \mathbf{2}$ group are more satisfactory for coatings.

In Figure 6 are presented the X ray diffraction (XRD) graphs of selected samples from the upper, lower and carbonate portions. In all the cases it is noticed the $10 \AA$ (II) peak asymmetry of hydromicas or illites. For [13] when illites are pure the peak may result from a compo-

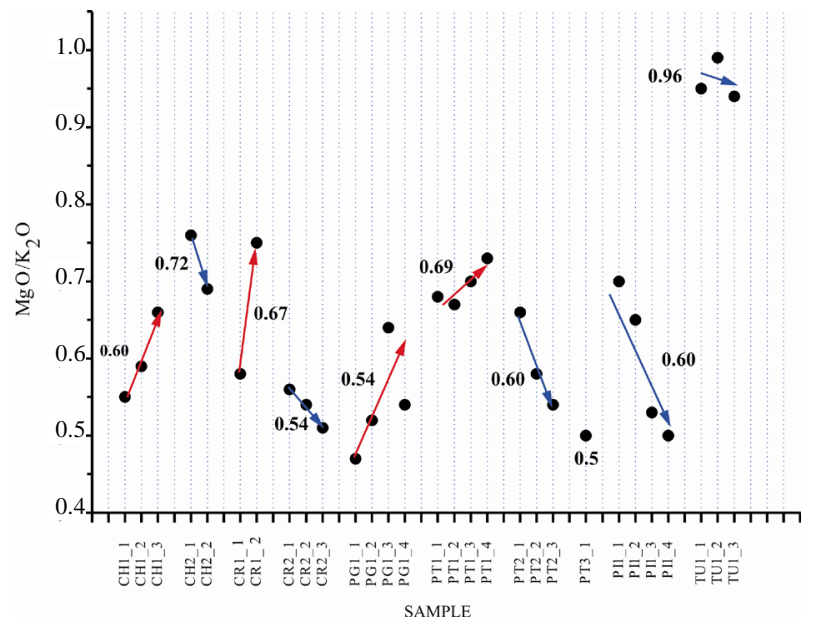

Figure 4. $\mathrm{MgO} / \mathrm{K}_{2} \mathrm{O}$ ratio range within each profile. The mean value for each mining front is indicated in the graph, in which the highest value correspond to carbonate samples that are discrepant in relation to the regional pattern and only occur locally.

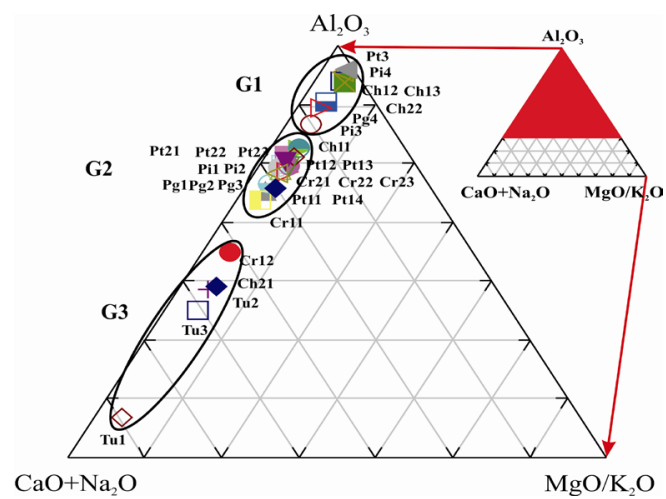

Figure 5. $\mathrm{Al}_{2} \mathrm{O}_{3} \_\left(\mathrm{CaO}+\mathrm{Na}_{2} \mathrm{O}\right) \_\mathrm{MgO} / \mathrm{K}_{2} \mathrm{O}$ diagram showing the weathering sequence of samples.

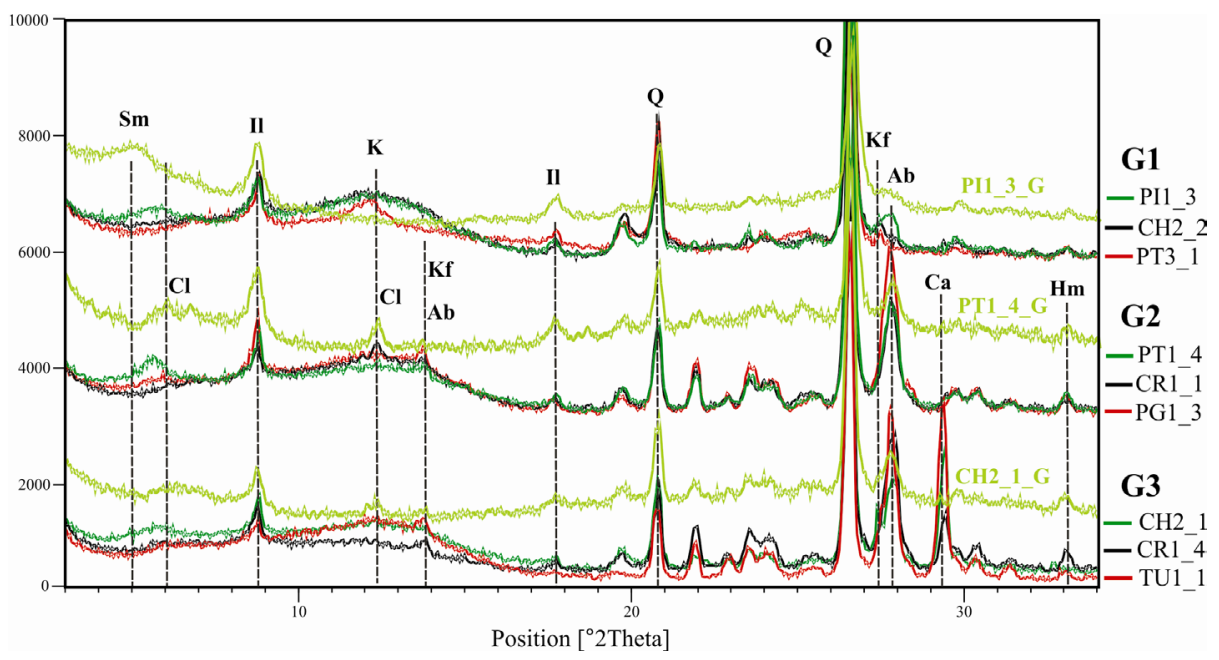

Figure 6. $\mathrm{X}$ ray diffraction graphs of selected samples from the upper, lower and high carbonate content portions. The PI1_3_G, PT1_4_G and CH2_1_G graphs correspond, respectively, to 2 $\mathrm{m}$ fraction treated with ethylene glycol (Sm, smectite; Cl, chlorite; Il, illite; K, kaolinite; Kf, K feldspar; Ab, albite; Q, quartz; Ca, calcite; Hm, hematite). 
sition of two primary peaks, one of $10 \AA$ and another between 10.2 and $10.4 \AA$, also a combination of illite and mixed-layer illite/smectite, at different crystallization levels depending on temperature and time of formation, can occur.

Another aspect that can be highlighted is feldspar content, since in the upper portion samples peaks that correspond to albite are small or absent while peaks of potassium feldspar are clearly observed (Figure 6). For the samples that present a ribbon left side to the illite main peak (PI1_3, PT1_4 e CH2_1) it was enclosed a graph regarding the fraction smaller than two microns treated with ethylene glycol (Figure 6). It is possible to observe that among the superior portion samples (G1) only PI1_3 presents expansiveness, fact that is reflected in a high dry mechanical resistance (Figure 7) and for the G2 group, PT1_4 also presents expansive clay minerals that contribute for a good mechanical resistance among the group samples (Figure 7), however the albite percentage is still high.

Generally ceramic bodies made with upper portion samples (G1) have a superior mechanical resistance when compared to samples from other groups, which is attributed to a better natural particle disintegration during grinding operation (Figure 7). The Pt3_1 sample, less resistant among G1 group, contains kaolinite as a weathering result, above all of sodium element $\left(\mathrm{Na}_{2} \mathrm{O}=\right.$ $0.09 \%)$ after albite hydrolyses, along with potassic feldspar remain and a proportional larger concentration of free quartz (Table 1 and Figure 6).

Particles from the lower portion samples (G2), due to higher hardness and diversified mineralogical composition, present shapes and sizes that influences packaging acquired during ceramic bodies pressing, resulting in a larger porosity and minor dry mechanical resistance, observed in Figure 7, in which four samples of less mechanical resistance belong to the inferior bench of the respective profile.

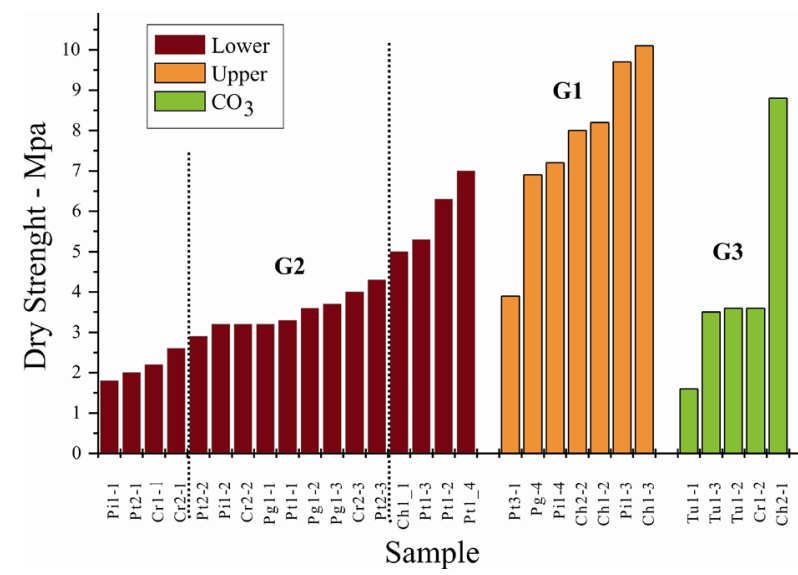

Figure 7. Mechanical resistance of pressed and dried ceramic bodies, measured with a three points fleximeter.
Among G3 group samples, CH2_1 contains expansive clay minerals that increases resistance and Tu1_1 a lot of carbonate and albite, considered non plasticizers minerals.

Observing the mechanical resistance of G2 group in increasing order, the first four belong to inferior benches of the respective mines and the last four, with larger mechanical resistance, to three superior benches of the same mine (Pt) containing well defined expansive clay minerals and CH1_1 that presents mixed layers expansive clay minerals, which provide high plasticity. The sequence of clay minerals that follows the illites in intermediate samples (G2) are chlorite to expansive chlorite with irregular stratifications in all cases, a mineralogical variation that corresponds to an increasing sequence of mechanical resistance.

The granulometric distribution of $\mathbf{G} \mathbf{1}$ group samples presents a pattern of frequency graphs (Figure 8) with sharp peaks as a result of medium size particles concentration in a lower range when compared to other groups, whose graphs are wider.
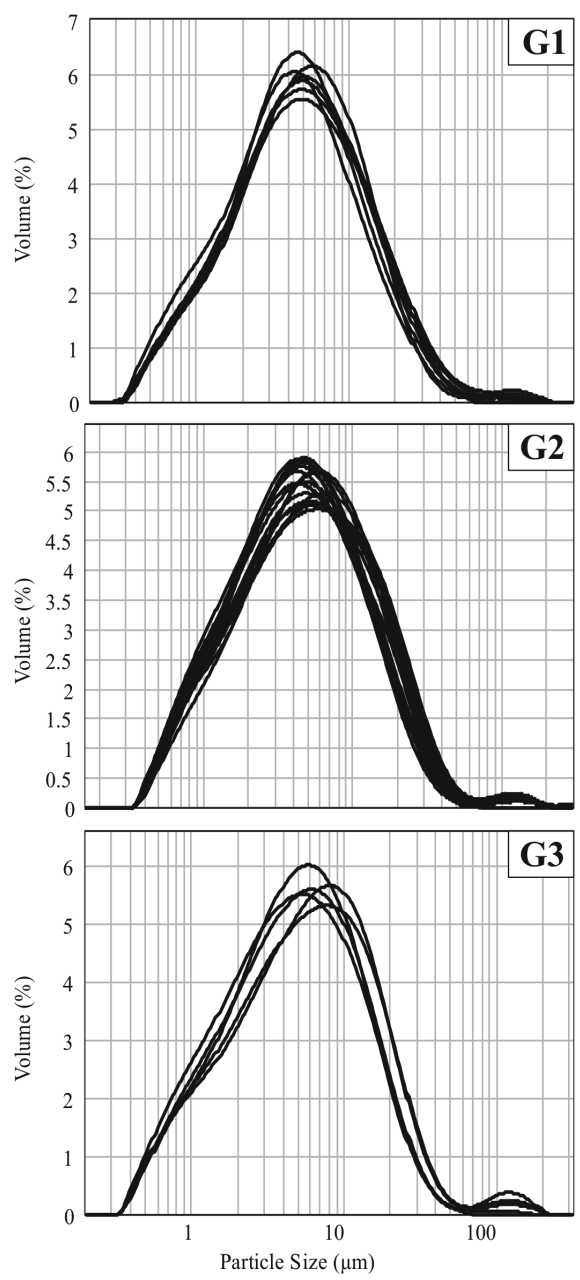

Figure 8. Particle size distribution after dry milling in a laboratory hammer-mill. 
Among the five carbonate samples, main differences regarding granulometric distribution are related to carbonate mode of occurrence, dispersed (which are thinner) and/or located in veins.

Figure 9 displays XRD graphs of selected samples from groups 1 and 2, where the differences between left peaks can be noticed. The samples of $\mathbf{G} 2$ group (Figure 9(B)) show better defined diffraction peaks due to a low weathering alteration, in which residual mineralogy is conserved along with the one acquired during diagenesis and hydrothermalism processes [13]. The more weathered samples G1 (Figure 9(A)), PT3_1 and Pi1_4 possess kaolinite, however the second one is less evolved and still conserves expansive structures poorly crystalized. In CH1_2 and CH1_3 samples (Figure 9(A)) only micaceous minerals show peaks, though with a more accentuated asymmetry to the left (see Natural graph), once the potassium output in specific layers and input of water and hydrated ions instead tend to generate expansion and the formation of smectites and subsequent kaolinites, depending on the leaching degree [14].

Graphs from Figure 9, upwards follow the sequence of lower to higher mechanical sequence. In G1 (Figure
9(A)) CH1_2 and CH1_3 have higher values than the ones where the weathering action resulted in kaolinite (poorly crystalized). In G2 (Figure 9(B)) the highest values correspond to samples with smectite, clay minerals normally of very thin particle size and that retain more water, thus providing more plasticity.

\section{Conclusions}

The $\mathrm{MgO} / \mathrm{K}_{2} \mathrm{O}$ ratio presents little variation with $\mathrm{SiO}_{2}$ increase, except for samples of $\mathrm{CaO}$ content greater than $3 \%$, which constitutes a particularity for the Corumbataí Formation clays in the studied region.

The chemical composition analysis allowed us to evaluate the differences presented by strata and mines. By using the $\mathrm{MgO} / \mathrm{K}_{2} \mathrm{O}$ indexes for each sample, it was possible to visualize the weathering sequence, which validates the chemical analysis as a control tool for clay selection as well as the composition control for masses and consequently variation of ceramic properties.

Mineralogical composition and weathering degree of rocks influence the granulometric distribution of milling, hence the packaging of particles during pressing process

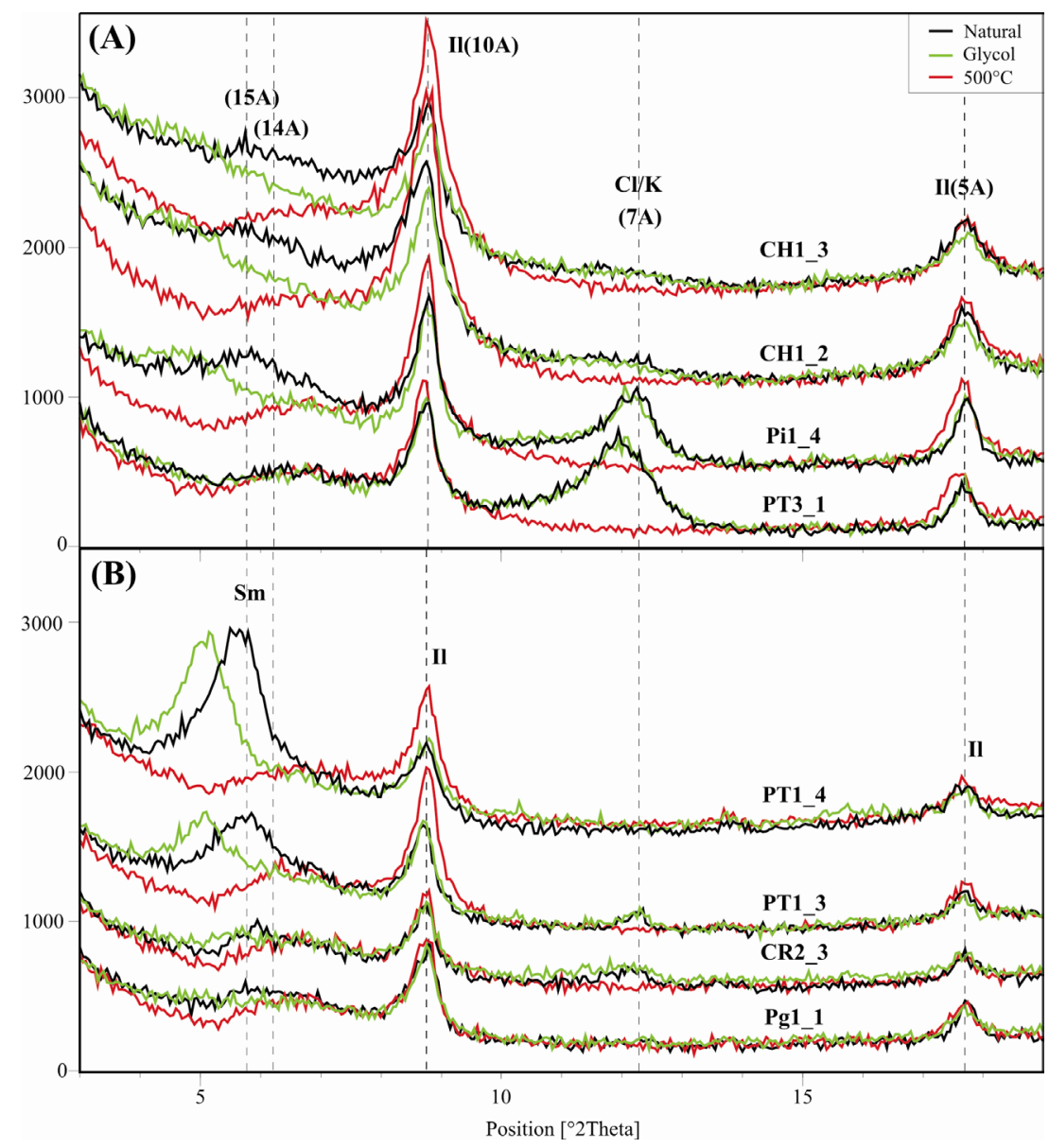

Figure 9. Granulometric fraction <2 $\mu \mathrm{m}$ of selected samples from G1 group (A) and G2 group (B). Sm, Smectite; Il, llite; K, kaolinite; $\mathrm{Cl}$, chlorite. 
and the properties of associated ceramic products.

The dry mechanical resistance tests of pressed ceramic bodies are directly related to the weathering state and the resulted mineralogy, in which smectites and expansive stratifications present the highest values among $\mathbf{G} 2$ group. In $\mathbf{G 1}$ group, samples that contain kaolinite have lower values than the ones that contain smectite-chlorite stratifications. Samples of $\mathbf{G} 3$ group present greater variations due to carbonate content and the quantity and types of associated clay minerals.

\section{REFERENCES}

[1] R. R. Rocha, "Propriedades Químico-Mineralógicas e Cerâmicas de Rochas da Formação Corumbataí: Aplicação na Diversificação de Produtos,” Ph.D. Thesis, Paulista StateUniversity, Rio Claro, 2012.

[2] V. J. Fúlfaro and A. Bjornberg, "Solos do Interior de São Paulo,” EDUSP, São Paulo, 1983.

[3] E. J. Milani, A. B. França and R. L. Schneider, "Bacia do Paraná,” Boletim de Geociências da Petrobrás, Vol. 8, No. 1,1994, pp. 69-82.

[4] M. M. T. Moreno, "Argilas: Composição Mineralógica, Distribuição Granulométrica e Consistência de Pastas,” Associate Professorship Thesis, Paulista State University, Rio Claro, 2012.

[5] M. M. T. Moreno, D. Bartolomeu and R. H. C. Lima, "Análise do Comportamento de Queima de Argilas e Formulações para Revestimento Cerâmico,” Cerâmica, Vol. 55, No. 335, 2009, pp. 286-295. http://dx.doi.org/10.1590/S0366-69132009000300008
[6] H. Rollinson, "Using Geochemical Data: Evaluation, Presentation, Interpretation,” Longman, Singapore, 1994.

[7] B. Velde, "Origin and Mineralogy of Clays,” Springer, Berlin, 1995. http://dx.doi.org/10.1007/978-3-662-12648-6

[8] K. B. Krauskopf, D. K. Bird, "Introduction to Geochemistry”, McGraw-Hill, New York, 1995.

[9] S. R. Christofoletti and M. M. T. Moreno, “Análise Quantitativa de Albita e sua Distribuição em Perfis de Argilas da Formação Corumbataí na região do Pólo Cerâmico de Santa Gertrudes-SP, Brasil,” Cerâmica Industrial, Vol. 18, No. 2, 2013, pp. 17-22.

[10] G. Faure, "Principles and Aplications of Inorganic Geochemistry,” Prentice Hall, Upper Saddle River, 1991.

[11] L. H. Godoy, M. M. T. Moreno and A. Zanardo, “Caracterização da Matéria Prima Cerâmica da Mina Tabajara (Limeira, SP),” Cerâmica, Vol. 57, No. 344, 2011, pp. 474-482. http://dx.doi.org/10.1590/S0366-69132011000400016

[12] S. R. Christofoletti, M. M. T. Moreno and A. Batezelli, “Análise de Fácies da Formação Corumbataí (Grupo passa Dois, Bacia do Paraná, Neopermiano), com Vista ao Emprego na Indústria de Revestimento Cerâmico”, Revista Brasileira de Geociências, Vol. 36, No. 3, 2006, pp. 488-498.

[13] A. Meunier and B. Velde, “Illite,” Springer, New York, 2004.

[14] J. B. Dixon, R. C. Dinauer and S. B. Weed, "Minerals in Soil Enviroments," Soil Science Society of America, Madison, 1977. 